\title{
Redox cycling of endogenous copper by thymoquinone leads to ROS-mediated DNA breakage and consequent cell death: putative anticancer mechanism of antioxidants
}

\author{
H Zubair ${ }^{1}$, HY Khan ${ }^{1}$, A Sohail ${ }^{1}$, S Azim ${ }^{1}$, MF Ullah ${ }^{1,2}$, A Ahmad $^{1,3}$, FH Sarkar ${ }^{\star, 3}$ and SM Hadi ${ }^{\star, 1}$
}

Plant-derived dietary antioxidants have attracted considerable interest in recent past for their chemopreventive and cancer therapeutic abilities in animal models. Thymoquinone (TQ) is the major bioactive constituent of volatile oil of Nigella sativa and has been shown to exert various pharmacological properties, such as anti-inflammatory, cardiovascular, analgesic, anti-neoplastic, anticancer and chemopreventive. Although several mechanisms have been suggested for the chemopreventive and anticancer activity of $T Q$, a clear mechanism of action of $T Q$ has not been elucidated. $T Q$ is a known antioxidant at lower concentrations and most of the studies elucidating the mechanism have centered on the antioxidant property. However, recent publications have shown that TQ may act as a prooxidant at higher concentrations. It is well known that plant-derived antioxidants can switch to prooxidants even at low concentrations in the presence of transition metal ions such as copper. It is well established that tissue, cellular and serum copper levels are considerably elevated in various malignancies. Copper is an important metal ion present in the chromatin and is closely associated with DNA bases, particularly guanine. Using human peripheral lymphocytes and comet assay, we first show that TQ is able to cause oxidative cellular DNA breakage. Such a DNA breakage can be inhibited by copper-chelating agents, neocuproine and bathocuproine, and scavengers of reactive oxygen species. Further, it is seen that TQ targets cellular copper in prostate cancer cell lines leading to a prooxidant cell death. We believe that such a prooxidant cytotoxic mechanism better explains the anticancer activity of plant-derived antioxidants.

Cell Death and Disease (2013) 4, e660; doi:10.1038/cddis.2013.172; published online 6 June 2013

Subject Category: Cancer

Thymoquinone (TQ) is the bioactive constituent of the volatile oil of Nigella sativa (54\%). It has been shown to exert anti-inflammatory, anti-oxidant and anti-neoplastic effects both in vitro and in vivo. Many investigators have shown that the growth inhibitory effects of $\mathrm{TQ}$ are specific to cancer cells. ${ }^{1-4}$ TQ showed significant anti-neoplastic activity against human pancreatic adenocarcinoma, uterine sarcoma and leukemic cell lines, while being minimally toxic to normal cells. ${ }^{4}$ The multidrug-resistant variants of human pancreatic adenocarcinoma, uterine sarcoma and leukemic cell lines, which are over 10-fold more resistant to the standard antineoplastic agents doxorubicin and etoposide as compared with their respective parental controls, were equally sensitive to TQ. ${ }^{4} \mathrm{TQ}$ also exerts anti-oxidant effects and inhibits inflammation in animal models and cell culture systems. ${ }^{5}$

$\mathrm{TQ}$ belongs to a family of quinones that can undergo enzymatic or non-enzymatic redox cycling with their corresponding semiquinone radicals to generate superoxide anion radicals. ${ }^{6} \mathrm{TQ}$ has been shown to inhibit growth in various cancer cell lines, including prostate cancer cells, but the mechanism of TQ-induced growth inhibition has not been delineated. TQ has been shown to induce apoptosis by p53-dependent ${ }^{2}$ and p53-independent ${ }^{7}$ pathways. Although $\mathrm{TQ}$ is a known antioxidant at lower concentrations, a number of recent publications report the pro-oxidant effects of TQ. ${ }^{8-11}$ Moreover, the antioxidant/prooxidant ability of TQ depends on the milieu where it is present. ${ }^{12}$ Compared with normal cells, preneoplastic cells and neoplastic cells have been shown to contain elevated levels of copper ${ }^{13}$ and may be more sensitive to electron transfer with antioxidants to generate reactive oxygen species (ROS). Therefore, DNA damage induced by antioxidants in the presence of redox-active metal $\mathrm{Cu}$ (II) may be an important pathway through which preneoplatic cells and neoplastic cells can be killed while normal cells survived. ${ }^{14}$

We have shown that various classes of plant polyphenols are able to cause oxidative breakage of cellular DNA either alone or in the presence of transition metal ions such as copper. ${ }^{14-18}$ We have hypothesized that the cytotoxic action

\footnotetext{
${ }^{1}$ Department of Biochemistry, Faculty of Life Sciences, Aligarh Muslim University, Aligarh, India; ${ }^{2}$ Prince Fahad Research Chair, Department of Medical Laboratory Technology, Faculty of Applied Medical Sciences, University of Tabuk, Tabuk, Kingdom of Saudi Arabia and ${ }^{3}$ Department of Pathology, Karmanos Cancer Institute, Wayne State University School of Medicine, Detroit, MI, USA

*Corresponding author: FH Sarkar, Department of Pathology, Karmanos Cancer Institute, Wayne State University School of Medicine, Detroit, MI 48201, USA. Tel: +1 313576 8327; Fax: +1 313576 8389; E-mail: fsarkar@med.wayne.edu.

or SM Hadi, Department of Biochemistry, Faculty of Life Sciences, Aligarh Muslim University, Aligarh 202002, India. +91 9897957998; E-mail: smhadi@vsnl.com Keywords: thymoquinone; prooxidant activity; anticancer; DNA breakage; copper

Abbreviations: TQ, thymoquinone; ROS, reactive oxygen species; TBA, 2-thiobarbituric acid; SOD, superoxide dismutase; DMSO, dimethyl sulfoxide; MTT, 3-(4,5-dimethylthiazol-2-yl)-2,5-diphenyltetrazolium bromide; TBARS, TBA-reactive substance
}

Received 18.3.13; accepted 03.4.13; Edited by A Finazzi-Agró 
of these compounds against cancer cells involves mobilization of endogenous copper and consequent prooxidant action. ${ }^{19,20}$ Toward validation of our hypothesis that anticancer mechanism of plant polyphenols involves mobilization of endogenous copper possibly chromatin-bound copper and the consequent prooxidant action, considerable evidence has been deduced over the years. ${ }^{16-18,21}$ In this paper using human peripheral lymphocytes, we first show that TQ can cause oxidative DNA breakage in cells through mobilization of endogenous copper ions. As a further proof of concept, we show that TQ inhibits proliferation and induces apoptosis in prostate cancer cell lines by reactive oxygen species through the redox cycling of endogenous copper. It has been well documented that copper concentrations are significantly elevated in all types of malignancies. Thus, this mechanism better explains the anticancer activity of plant-derived antioxidants with varied structures.

\section{Results}

Formation of complexes involving calf thymus DNA/ Cu(II) with TQ. Figure 1a shows the effect of addition of increasing molar base pair ratios of calf thymus DNA on the fluorescence emission spectra of TQ excited at $255 \mathrm{~nm}$. Such an addition resulted in a dose-dependent enhancement of the fluorescence. However, there was no significant shift in the $\lambda_{\text {max }}$ emission, suggesting a simple mode of binding of DNA and TQ. Similarly, binding of copper ions to TQ was studied by the effect of increasing $\mathrm{Cu}$ (II) molar ratios on the fluorescence emission spectra of the compound. The result shown in Figure $1 \mathrm{~b}$ indicates binding as addition of $\mathrm{Cu}$ (II) causes quenching of TQ fluorescence. The control (native DNA alone and copper alone) when excited at the same wavelength $(255 \mathrm{~nm})$ did not interfere with the emission spectrum, thus confirming the binding of $\mathrm{TQ}$ to copper ions as well as DNA.

Detection of TQ-induced $\mathbf{C u}(\mathrm{I})$ production by bathocuproine. The production of $\mathrm{Cu}(\mathrm{I})$, as a result of reduction of $\mathrm{Cu}$ (II) by $\mathrm{TQ}$, was analyzed using bathocuproine, which is a $\mathrm{Cu}(\mathrm{I})$-specific sequestering agent. Bathocuproine binds specifically to the reduced form of copper, $\mathrm{Cu}(\mathrm{I})$, but not to the oxidized form, $\mathrm{Cu}(\mathrm{II}) .^{22}$ The $\mathrm{Cu}(\mathrm{I})$-bathocuproine complex exhibits an absorption maximum at $480 \mathrm{~nm}$. As shown in Figure 2, neither $\mathrm{Cu}(\mathrm{II})$ nor $\mathrm{TQ}$ interfere with the maxima, $\mathrm{TQ}+\mathrm{Cu}(\mathrm{II})$ react to generate $\mathrm{Cu}(\mathrm{I})$, which complexes with bathocuproine as evidenced by the peak appearing at $480 \mathrm{~nm}$. The result shows that $\mathrm{TQ}$ is able to reduce $\mathrm{Cu}(\mathrm{II})$ to $\mathrm{Cu}(\mathrm{I})$ and may contribute to the redox cycling of the metal.

Generation of hydroxyl radicals by $\mathrm{TQ}$. Rahman et al. ${ }^{23}$ have previously shown that during the reduction of $\mathrm{Cu}(\mathrm{II})$ to $\mathrm{Cu}(\mathrm{I})$, reactive oxygen species such as hydroxyl radicals are formed, which may serve as the proximal DNA cleaving agent. Therefore, the capacity of $\mathrm{TQ}$ to generate hydroxyl radical in the presence of $\mathrm{Cu}(\mathrm{II})$ was examined. The assay is based on the fact that degradation of DNA by hydroxyl radicals results in the release of 2-thiobarbituric acid (TBA)reactive material, which forms a colored adduct with TBA
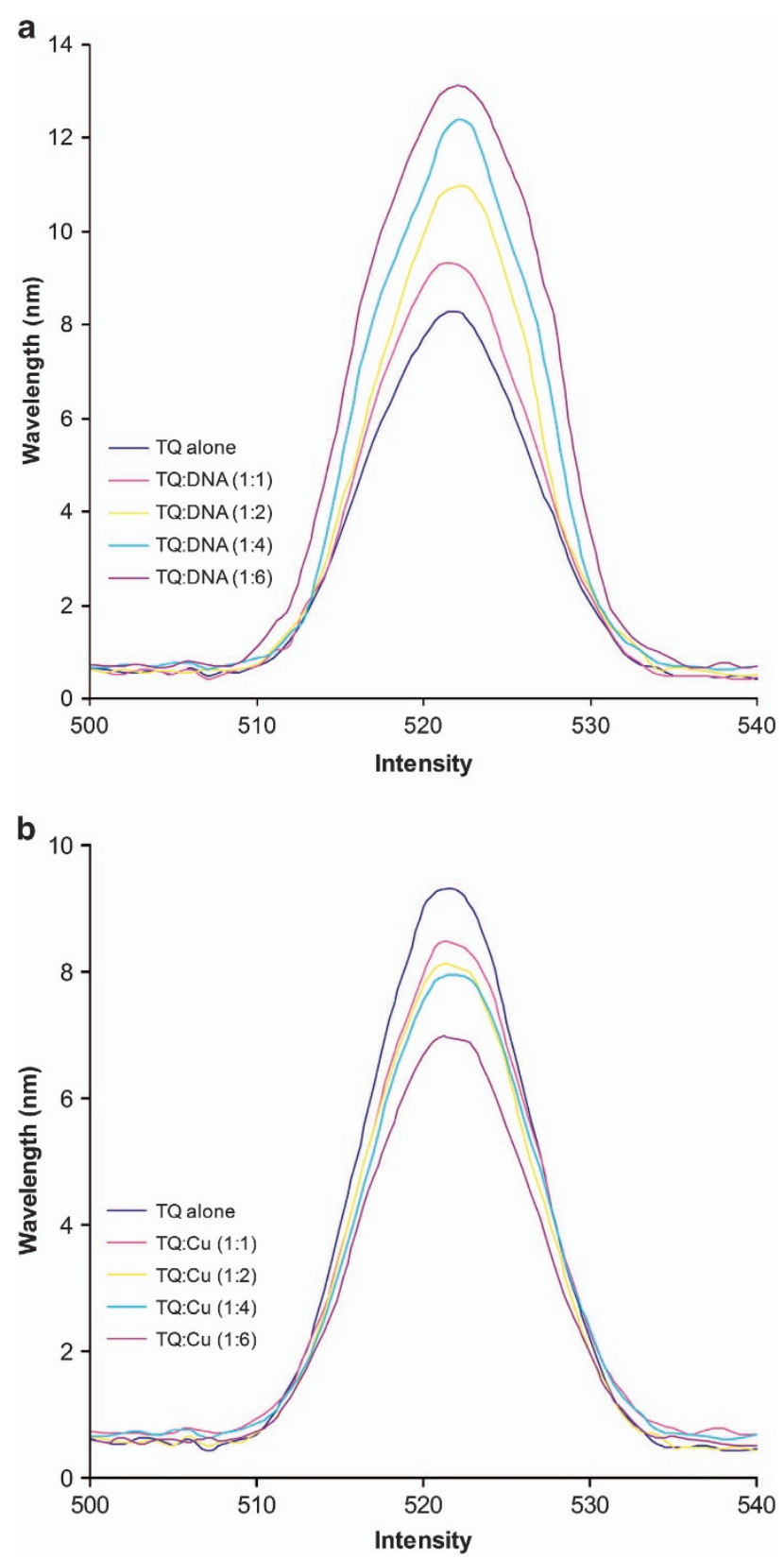

Figure 1 Effect of increasing (a) native DNA base pair molar ratios and (b) copper concentrations on the fluorescence emission spectra of $T Q$. TQ (in $10 \mathrm{mM}$ Tris- $\mathrm{HCl}, \mathrm{pH} 7.5$ ) was excited at $255 \mathrm{~nm}$ in the presence of (a) increasing native DNA base pair molar ratios and (b) increasing concentration of $\mathrm{Cu}(\mathrm{II})$ and the emission spectra were recorded between 500 and $540 \mathrm{~nm}$

whose absorbance is read at $532 \mathrm{~nm} .{ }^{24}$ The result given in Figure 3 clearly shows that increasing concentration of the $\mathrm{TQ}$ leads to a progressive increase in the formation of hydroxyl radicals.

Cleavage of pBR322 DNA treated with TQ and $\mathrm{Cu}(\mathrm{II})$. To examine the efficacy of TQ-Cu(II) system in DNA cleavage, in Figure 4, the ability of TQ to cause cleavage of supercoiled plasmid pBR322 DNA in the presence of copper ions was tested. As can be seen from the ethidium bromide-stained 


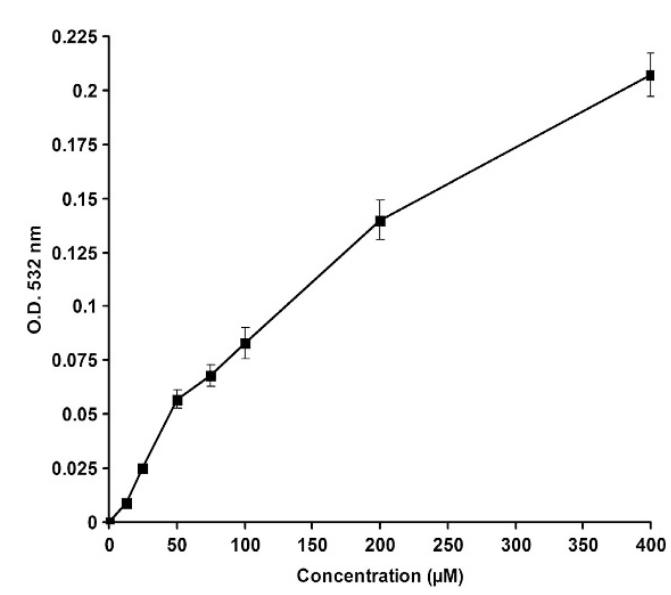

Figure 2 Reduction of $\mathrm{Cu}(\mathrm{II})$ to $\mathrm{Cu}(\mathrm{I})$ by $\mathrm{TQ}$. Detection of TQ-induced $\mathrm{Cu}(\mathrm{I})$ production by bathocuproine. Reaction mixture contained $10 \mathrm{mM}$ Tris- $\mathrm{HCl}(\mathrm{pH} 7.5)$ along with $300 \mu \mathrm{M}$ bathocuproine and indicated concentrations of the following: bathocuproine $+100 \mu \mathrm{M} \mathrm{Cu}(I \mathrm{I})$; bathocuproine $+50 \mu \mathrm{M} \mathrm{TQ}$; bathocuproine +50 $\mu \mathrm{MTQ}+100 \mu \mathrm{M} \mathrm{Cu}(\mathrm{II})$

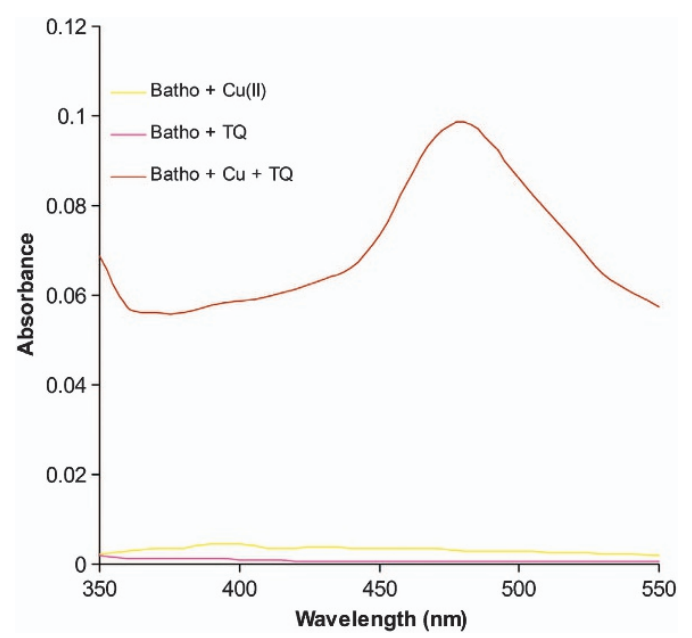

Figure 3 Generation of hydroxyl radical generation by TQ. Formation of hydroxyl radicals as a function of increasing concentration of $T Q$ in the presence of $\mathrm{Cu}(\mathrm{II})$. The reaction mixture $(0.5 \mathrm{ml})$ contained $100 \mu \mathrm{g}$ calf thymus DNA as substrate, $50 \mu \mathrm{M} \mathrm{Cu}(\mathrm{II})$ and indicated concentrations of $\mathrm{TQ}$ and incubated at $37^{\circ} \mathrm{C}$ for $30 \mathrm{~min}$. Hydroxyl radical formation was measured by determining the TBA-reactive material. All values reported are mean \pm S.E.M. of three independent experiments

agarose gel pattern, $30 \mu \mathrm{M}$ copper alone does not cause significant DNA cleavage. Although TQ alone at relatively higher concentration of $150 \mu \mathrm{M}$ leads to some DNA cleavage, increasing concentrations of TQ $(50-150 \mu \mathrm{M})$ in the presence of $30 \mu \mathrm{M}$ copper leads to progressive increase in the generation of open circular topological structures of plasmid DNA, demonstrating that TQ is capable of DNA degradation in the presence of copper ions, suggesting that an antioxidant-DNA-Cu system is physiologically feasible and could be of biological importance.

DNA breakage by TQ in human peripheral lymphocytes. Increasing concentrations of TQ $(0-40 \mu \mathrm{M})$ alone and in the presence of added $\mathrm{CuCl}_{2}(25 \mu \mathrm{M})$ were tested for DNA

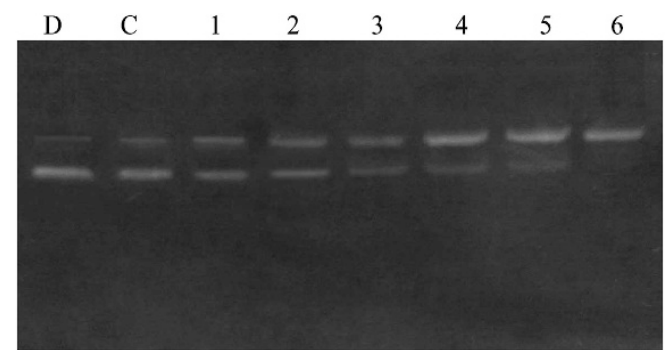

Figure 4 Agarose gel electrophoretic pattern of ethidium bromide-stained pBR322 plasmid DNA after treatment with TQ in the absence and presence of copper. Agarose gel electrophoretic pattern of ethidium bromide-stained pBR322 DNA after treatment with $\mathrm{TQ}$ and $\mathrm{Cu}(\mathrm{III})$. Reaction mixtures were incubated at $37^{\circ} \mathrm{C}$ for $1 \mathrm{~h}$ in dark. Lane D: pBR322 DNA alone; lane C: pBR322 DNA + Cu (II) $30 \mu \mathrm{M}$; lanes 1, 2, 3: pBR322 DNA + TQ $(50,100,150 \mu \mathrm{M}$, respectively); lanes 4, 5, 6: pBR322 DNA $+\mathrm{Cu}(\mathrm{II}) 30 \mu \mathrm{M}+\mathrm{TQ}(50,100,150 \mu \mathrm{M}$, respectively)

breakage in isolated human peripheral lymphocytes using comet assay. The corresponding comet tail length is plotted as a function of compound concentration in Figure 5 . It is seen that although TQ alone causes breakage of cellular DNA, the degree of such breakage is significantly enhanced in the presence of $\mathrm{Cu}(\mathrm{II}) . \mathrm{Cu}(\mathrm{II})(25 \mu \mathrm{M})$ controls were similar to untreated lymphocyte without any significant DNA breakage. The results clearly establish that TQ-Cu(II) system is capable of DNA breakage in isolated lymphocytes.

The DNA breakage capacity of TQ in whole lymphocytes and nuclei was also compared. As in the lysed version of the comet assay, membrane and cytoplasmic barrier are eliminated, it would be reasonable to assume that the compounds are able to directly interact with the cell nuclei. Thus, considerably greater DNA breakage should be observed in the lysed version as compared with the standard version where intact lymphocytes are used. Increasing concentrations $(0-40 \mu \mathrm{M})$ of TQ (Figure $5 \mathrm{~b})$ was tested for DNA breakage in intact lymphocytes and compared with that observed with lymphocyte nuclei. It is seen that the rate of tail formation is considerably greater in the case of lysed version, suggesting that $T Q$ is able to directly interact with the nuclei when lysed version of comet assay is used.

The DNA breakage induced by TQ in intact lymphocytes and lymphocyte nuclei has been assessed in the presence of $\mathrm{Cu}(\mathrm{I})$ specific chelators neocuproine and bathocuproine (Figures $5 \mathrm{c}$ and d). Incubation of Iymphocytes with neocuproine (a cell membrane permeable copper chelator) inhibited DNA degradation in intact lymphocytes. Bathocuproine disulphonate (the water soluble membrane impermeable analog of neocuproine), which is unable to permeate through the cell membrane, did not cause such inhibition. This study has further shown that TQ is able to degrade DNA in cell nuclei and that such DNA degradation is inhibited by neocuproine as well as bathocuproine disulphonate (both of which are able to permeate the nuclear pore complex), suggesting that nuclear copper is mobilized in this reaction. It may be mentioned that $\mathrm{Fe}^{3+}$ and $\mathrm{Cu}^{2+}$ ions are the most redox active of the metal ions present in living cells. Also, copper and zinc are the major metal ions present in the nucleus. ${ }^{25}$ To examine the possible involvement of iron and zinc in TQ-induced DNA breakage, the effect of desferrioxamine mesylate (a Fe(II)-specific chelator) 

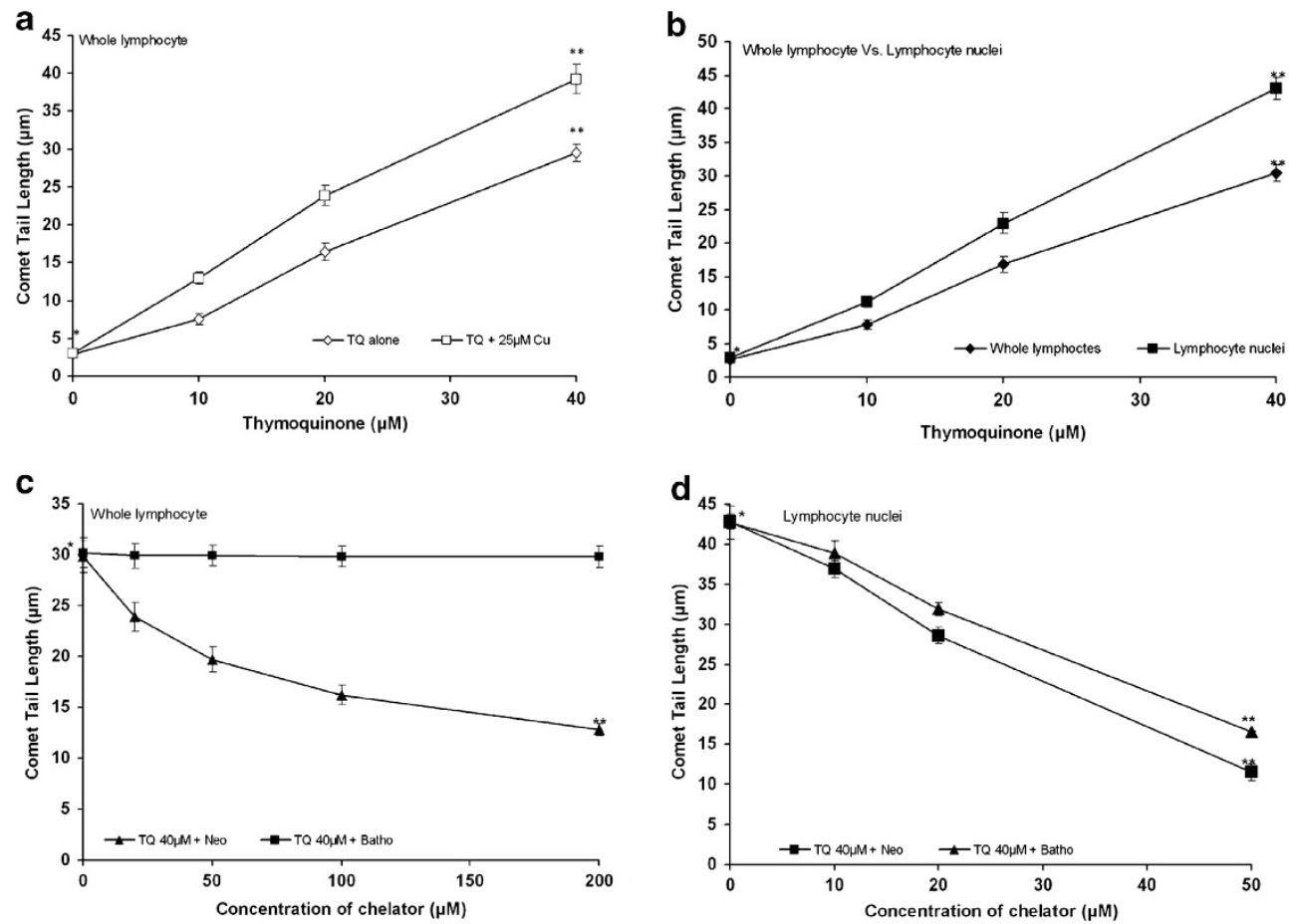

Figure 5 DNA breakage by TQ in human peripheral lymphocytes. (a) Whole lymphocyte cells were incubated in microfuge tubes with reaction mixture at $4{ }^{\circ} \mathrm{C}$ for $1 \mathrm{~h}$ in dark. Reaction mixture contained RPMI $(400 \mu \mathrm{l}), \mathrm{Ca}^{2+}$ - and $\mathrm{Mg}^{2+}$-free PBS, increasing concentrations of TQ $(0-40 \mu \mathrm{M})$, alone $(\diamond)$ and with fixed concentration of $\mathrm{Cu}(\mathrm{II})$ $(25 \mu \mathrm{M})(\square)$ and processed further for comet assay. (b) Comparison of DNA breakage by TQ in intact lymphocytes and lymphocyte nuclei as measured by comet assay. Whole lymphocyte cells $(\checkmark) /$ lymphocyte nuclei $(\boldsymbol{\square})$ embedded in agarose were incubated with the reaction mixture containing indicated concentrations of TQ $(0-40 \mu \mathrm{M})$ at $4{ }^{\circ} \mathrm{C}$ for $1 \mathrm{~h}$ and processed further for comet assay. Whole lymphocyte (c)/lymphocyte nuclei (d) embedded in agarose were incubated with the reaction mixture (2.0 ml) containing TQ $(40 \mu \mathrm{M})$ and indicated concentrations of membrane permeable copper chelator (Neo, neocuproine); membrane impermeable copper chelator (Batho, bathocuproine) at $4{ }^{\circ} \mathrm{C}$ for $1 \mathrm{~h}$ and processed further for comet assay. Values reported are mean \pm S.E.M. of three independent experiments. Error bars denote \pm S.E.M. ${ }^{* \star} P<0.05$ when compared with * (untreated control cells)

and histidine (a zinc-specific chelator) has been examined on DNA breakage in lymphocytes and lymphocyte nuclei. It is seen that although desferrioxamine mesylate is able to inhibit TQ-induced DNA breakage in whole lymphocytes to a certain degree, it did not provide any protection on TQ-induced DNA breakage in cell nuclei (results not shown). Moreover, histidine was unable to inhibit TQ-induced DNA breakage in whole lymphocytes as well as lymphocyte nuclei. These results indicate that TQ-induced DNA breakage in lymphocytes involves mobilization of endogenous copper, possibly chromatin-bound copper and that $\mathrm{Cu}(\mathrm{I})$ is an intermediate in the pathway. Thus, demonstrating and copper-mediated cellular DNA breakage property of antioxidants is possible in vitro.

Effect of scavengers of ROS on TQ-induced DNA breakage. Table 1 gives the results of an experiment where various scavengers of ROS, such as superoxide dismutase (SOD), catalase and thiourea, were tested for their effect on TQ-induced DNA breakage in intact lymphocytes and lymphocyte nuclei. SOD and catalase remove superoxide and $\mathrm{H}_{2} \mathrm{O}_{2}$, respectively, and thiourea removes hydroxyl radicals. All scavengers caused a significant inhibition of DNA breakage as evidenced by decreased tail lengths. It may be mentioned that because of the site-specific nature of the reaction of hydroxyl radicals with DNA it is difficult for any trapping molecules to intercept them completely. ${ }^{26}$ Thus, complete
Table 1 Effect of scavengers of reactive oxygen species on TQ-induced DNA breakage in intact lymphocyte and lymphocyte nuclei

\begin{tabular}{|c|c|c|c|c|}
\hline \multirow[t]{2}{*}{ Treatment } & \multicolumn{2}{|c|}{ Whole lymphocyte } & \multicolumn{2}{|c|}{ Lysed cells } \\
\hline & Tail length & $\begin{array}{c}\% \\
\text { Inhibition }\end{array}$ & Tail length & $\begin{array}{c}\% \\
\text { Inhibition }\end{array}$ \\
\hline \multirow{5}{*}{$\begin{array}{l}\text { None } \\
\text { TQ }(40 \mu \mathrm{M}) \\
\quad+\mathrm{SOD} \\
(100 \mu \mathrm{g} / \mathrm{ml}) \\
\text { + Catalase } \\
\text { (100 } \mu \mathrm{g} / \mathrm{ml}) \\
\text { + Thiourea } \\
\text { (1 } \mathrm{mM})\end{array}$} & $2.23 \pm 0.09^{1}$ & - & $2.39 \pm 0.07^{1}$ & - \\
\hline & $29.28 \pm 1.42^{2}$ & - & $42.86 \pm 2.04^{3}$ & - \\
\hline & $12.26 \pm 0.82^{3}$ & 58 & $16.28 \pm 0.94^{3}$ & 62 \\
\hline & $13.41 \pm 0.88^{3}$ & 54 & $15.41 \pm 0.83^{3}$ & 64 \\
\hline & $15.46 \pm 1.35^{3}$ & 51 & $15.80 \pm 1.35^{3}$ & 65 \\
\hline
\end{tabular}

Whole lymphocytes and lymphocytes nuclei were layered with reaction mixture containing TQ $(40 \mu \mathrm{M})$ in the presence of scavengers of ROS (at indicated concentrations) at $4^{\circ} \mathrm{C}$ for $1 \mathrm{~h}$ and processed further for comet assay as described in 'Materials and Methods'.

${ }^{2} P<0.05$ when compared with ${ }^{1}$

${ }^{3} P<0.05$ when compared with ${ }^{2}$

inhibition of DNA breakage in the presence of scavengers of ROS is not seen. The results indicate that superoxide anion and $\mathrm{H}_{2} \mathrm{O}_{2}$ are essential components in the pathway that leads to the formation of hydroxyl radical and other species, which would be the proximal DNA cleaving agents. Thus, it is suggested that a mechanism involving reactive oxygen species is responsible for cellular DNA breakage induced by TQ. 
Effect of preincubation of lymphocytes with thiourea/ neocuproine on TBA-reactive substance (TBARS). As mentioned above, it is suggested that lymphocyte DNA

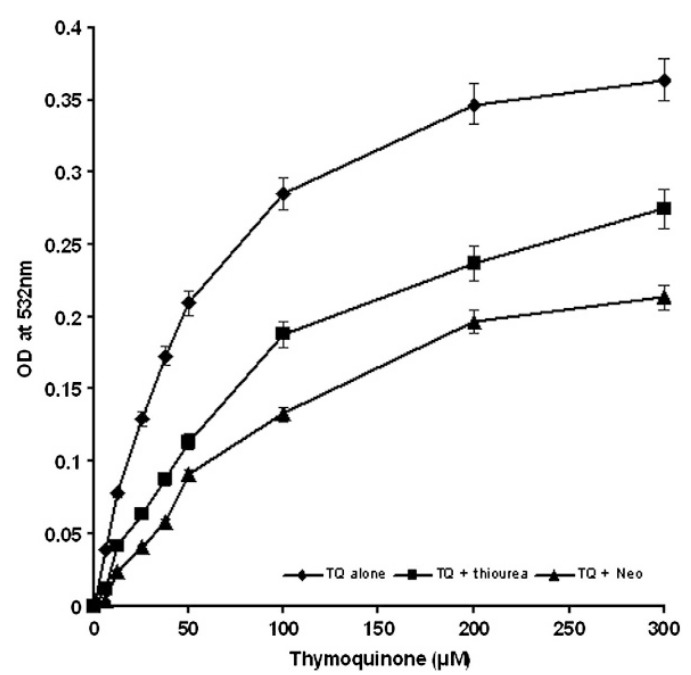

Figure 6 Effect of preincubation of lymphocyte with neocuproine and thiourea on TBARS generated by increasing concentrations of TQ. Effect of preincubation of lymphocyte with neocuproine and thiourea on TBARS generated by increasing concentrations of TQ. Lymphocyte cells were preincubated with fixed concentration of neocuproine and thiourea for $30 \mathrm{~min}$ at $37^{\circ} \mathrm{C}$ after which it was further incubated for $1 \mathrm{~h}$ in the presence of increasing concentrations of TQ. Values reported are mean of three independent experiments breakage induced by the TQ is the result of the generation of ROS in situ. Oxygen radical damage to deoxyribose or DNA is considered to give rise to TBA-reactive material. ${ }^{24}$ In the experiment shown in Figure 6, the formation of TBARS as a measure of oxidative stress in lymphocytes with increasing concentrations of TQ has been determined. The effect of preincubating the cells with neocuproine and thiourea was also studied. It was seen that there is a dose-dependent increase in the formation of TBARS in lymphocytes. However, when cells were preincubated with neocuproine and thiourea there was a considerable decrease in the rate of formation of TBARS by TQ. The results given in Figure 5 along with the above results of comet assay indicate that both DNA breakage and oxidative stress in cells is inhibited by $\mathrm{Cu}(\mathrm{I})$ chelation and scavenging of reactive oxygen. Therefore, it can be concluded that the formation of ROS by $T Q$ in lymphocytes involves its interaction with intracellular copper as well as its reduction to $\mathrm{Cu}(\mathrm{I})$. In order to examine the possibility of auto-oxidation of $\mathrm{TQ}$ in cell culture media and further generation of ROS, we determined the formation of $\mathrm{H}_{2} \mathrm{O}_{2}$ by the TQ in the incubation medium (RPMI) and found the rate of $\mathrm{H}_{2} \mathrm{O}_{2}$ production by $T Q$ is significantly negligible (result not shown). The cellular DNA breakage by $\mathrm{TQ}$ antioxidant observed in our studies is not the result of extracellular production of $\mathrm{H}_{2} \mathrm{O}_{2}$ in the incubation medium.

Inhibition of cell proliferation and induction of apoptosis in prostate cancer cell lines treated with TQ. Cells from prostate cancer cell lines PC3, LNCaP, DU145 and C42B

b Inhibition of cell proliferation by TQ in presence of metal chelators
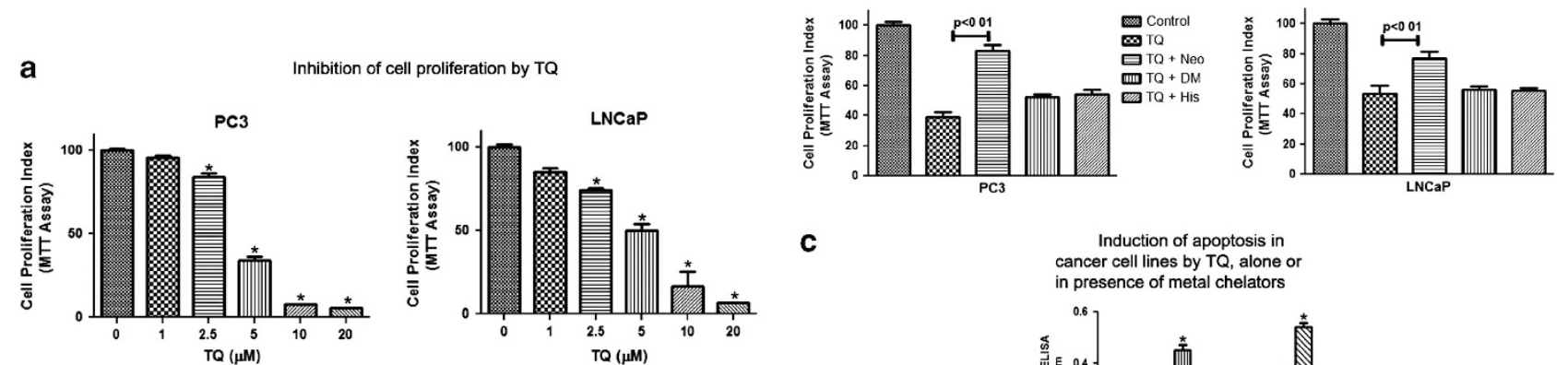

C
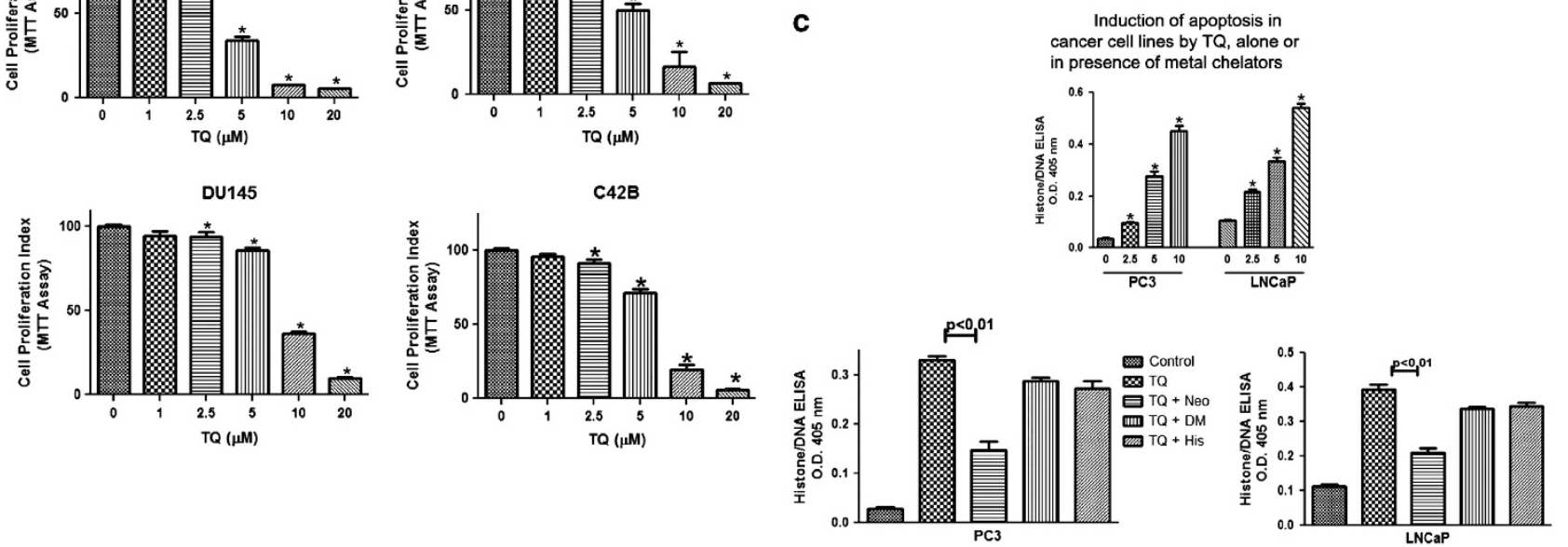

Figure 7 Effect of TQ on cell proliferation and induction of apoptosis in prostate cancer cells. (a) The effect of TQ on cell growth in prostate cancer cell lines as detected by MTT assay. The cells were incubated with indicated concentrations of TQ for $72 \mathrm{~h}$. (b) The effect of copper chelator neocuproine (Neo), iron chelator desferrioxamine mesylate (DM) and zinc chelator histidine (His) on TQ-induced cell growth inhibition in PC3 and LNCaP prostate cancer cells as detected by MTT assay. The cells were incubated with $5 \mu \mathrm{M}$ TQ in the presence of $50 \mu \mathrm{M}$ metal-specific chelator for $72 \mathrm{~h}$ and MTT assay performed. (c) The Cell Death Detection ELISA Kit (Roche) was used to detect apoptosis in PC3 and $\mathrm{LNCaP}$ prostate cancer cells treated with increasing concentrations of TQ as indicated and the effect of $50 \mu \mathrm{M}$ metal chelators on TQ-induced apoptosis on PC3 and LNCaP cells. Cells were incubated with $5 \mu \mathrm{M} \mathrm{TQ}$ alone or in the presence of copper chelator neocuproine (Neo), iron chelator desferioxamine mesylate (DM) and zinc chelator histidine (His). All results are expressed as percentage of control \pm S.E. of triplicate determinations from three independent experiments. ${ }^{*} P<0.01$ when compared with untreated (control) cells 
Table 2 Effect of ROS scavengers on TQ-induced apoptosis in cancer cell lines

\begin{tabular}{ccc}
\hline Cell lines & Apoptosis (folds) & $\begin{array}{c}\text { Effect of scavengers } \\
\text { (\% inhibition) }\end{array}$ \\
\hline PC3 & $-\overline{8}$ \\
Untreated & 2.8 & \\
TQ & $1.29^{\star}$ & 53.93 \\
+ TU & $1.59^{\star}$ & 43.21 \\
+ SOD & $1.72^{\star}$ & 38.57 \\
+ Cat & & \\
LNCaP & $-\overline{3}$ & \\
Untreated & 3.3 & 63.94 \\
TQ & $1.19^{\star}$ & 49.39 \\
+ TU & $1.67^{\star}$ & 44.85 \\
+ SOD & $1.82^{*}$ & \\
+ Cat & & \\
\hline
\end{tabular}

PC3 and LNCaP prostate cancer cell lines were incubated with different ROS scavengers, and treated with $\mathrm{TQ}$.

$\mathrm{TQ}, 5 \mu \mathrm{M}$; TU, $700 \mu \mathrm{M}$ thiourea; SOD, $100 \mu \mathrm{g} / \mathrm{ml}$ superoxide dismutase; Cat, $100 \mu \mathrm{g} / \mathrm{ml}$ catalase.

${ }^{\star} P<0.05$ compared with treated control.

were treated with varying concentrations of $\mathrm{TQ}(0-20 \mu \mathrm{M})$ for $72 \mathrm{~h}$. As can be seen from the Figure 7a, TQ caused a clear dose-dependent inhibition of cell proliferation in all cell lines tested. Further experiments were then carried out using $5 \mu \mathrm{M}$ TQ on prostate cancer cell lines PC3 and LNCaP as at this concentration these cell lines were found to exhibit maximum sensitivity to TQ treatment. We have shown in Figure 7 that the DNA breakage effect of TQ is inhibited in the presence of copper-specific chelators in comet assay, thus in order to verify that the cytotoxic action of $\mathrm{TQ}$ in cancer cells is also copper mediated, prostate cancer cell lines PC3 and LNCaP were treated with $5 \mu \mathrm{M} \mathrm{TQ}$ in the presence of metal-specific chelators. As can be seen in the Figure $7 \mathrm{~b}$, neocuproine (Cu-specific chelator) significantly inhibits the cytotoxic effect of TQ as compared with desferrioxamine (Fe-specific chelator) and histidine ( $\mathrm{Zn}$-specific chelator) in both the cell lines.

The results obtained from DNA-Histone ELISA (Figure 7c) clearly show that the exposure of prostate cancer cells to increasing concentrations of TQ $(0-10 \mu \mathrm{M})$ leads to a rise in absorbance at $405 \mathrm{~nm}$, because of enhanced internucleosomal fragmentation. Further, in the presence of neocuproine, TQ-induced apoptosis was significantly inhibited (Figure 7b), whereas desferrioxamine and histidine were unable to protect the cells. Thus, again suggesting the role of copper in TQ-mediated cell death.

TQ-induced apoptosis in prostate cancer cell lines is mediated by ROS. As observed in above, TQ-induced DNA breakage in lymphocytes is inhibited by scavengers of ROS. In order to examine the involvement of ROS in TQ-mediated apoptosis in cancer cells, the effect of scavengers of ROS-SOD, catalase and thiourea - was tested on TQ-induced cytotoxic action against cancer cell lines. All three scavengers of ROS significantly inhibited the apoptotic activity of TQ in both the cancer cell lines (Table 2). From the data it is concluded that the cytotoxic action of TQ is mediated by ROS.

\section{Discussion}

Cancer is a genetic disease that involves a number of inherited genetic alterations leading to changes in cell physiology, following progression and the development in to malignant tumors. Recently, Curtis et al. ${ }^{27}$ have suggested that breast cancer can be sub-categorized in to 10 sub-groups depending upon the inherited and acquired mutational variants. This leads to the suggestion that it is quite unlikely for the development of a single drug or even a combination of drugs targeting genetic abnormalities for the management or prevention of cancer. However, in all types of cancer there are certain metabolic changes that have been found to be common. The abundance of certain metabolic enzymes and transporters has been suggested to result in poor clinical outcome of the treatment of various forms of cancer. Elevated levels of copper have been reported in studies estimating the levels of different metal in tumors.

It is generally understood that antioxidants counteract ROS production and inhibit the ROS-induced oxidative DNA damage and therefore reduce the risk of cancer. However, some data in the literature suggests that the antioxidant properties of such compounds may not fully account for their chemopreventive and therapeutic properties. ${ }^{26,28}$ Many such plant-derived antioxidants have been shown to be capable of inducing apoptosis through the induction of ROS in different cancer cell lines. ${ }^{28-30}$ Over the last several years, this laboratory has extensively characterized oxidative DNA cleavage reactions mediated by polyphenolic antioxidants in the presence of copper ions. ${ }^{31-34}$ The above results provide evidence for the reduction of $\mathrm{Cu}(\mathrm{II})$ to $\mathrm{Cu}(\mathrm{I})$ by $\mathrm{TQ}$ and the possible formation of a ternary complex of the TQ-Cu(II)-DNA is formed. The major conclusions that are drawn from these results are (i) TQ is able to cause DNA breakage in the absence of added copper ions in lymphocytes presumably through mobilization of endogenous copper ions; this redox cycling of copper leads to the generation of various ROS, particularly the hydroxyl radical, which may serve as the proximal DNAcleaving agent; (ii) TQ induces a dose-dependent decrease in the cell proliferation of prostate cancer cell lines; the compound-induced cell proliferation inhibition and apoptosis induction in cancer cells are reversed in the presence of copper chelator, neocuproine, confirming the role of copper in the cytotoxic action of the antioxidants; (iii) further, the redox cycling of copper in the presence of TQ leads to the generation of ROS as evidenced by the decrease in apoptosis induction in the presence of scavengers of ROS. Thus, providing further evidence and identifying copper as a molecular target for the cancer cell inhibition property of antioxidant TQ.

It has been reported that several chemopreventive agents that are antioxidants at some concentrations become prooxidants at other concentrations. ${ }^{35}$ Several lines of evidence suggest that $\mathrm{TQ}$ has potent anion scavenging abilities in different models. ${ }^{36,37}$ However, TQ with its respective semiquinone radicals may generate superoxide anion radicals. $^{6}$ Evidence in the literature shows that various quinones (e.g., furanonaphthoquinones, pyrrolo[2,1-c][1,4] benzodiazepine-anthraquinone, 2-acylamine-1,4-napthoquinone and 1,4-napthoquinone) induce apoptosis in cancer cells by generating ROS. ${ }^{38-40}$ Recent studies have shown that TQ-induced apoptosis in colon cancer and prostate cancer cell lines is mediated by ROS. ${ }^{11,12}$

These results place $T Q$ in a class of plant-derived antioxidants, such as flavonoids, ${ }^{29}$ tannins, ${ }^{41}$ catechins $^{34}$ 
stilbenes ${ }^{16}$ and ascorbic acid ${ }^{42}$ (known to possess anticancer properties), which also exhibit prooxidant DNA-damaging properties. The generation of oxygen radicals in the proximity of DNA is well established as a cause of strand scission. ${ }^{23,29,41}$ It is generally recognized that such reactions with DNA are preceded by the association of the ligand with DNA, followed by the production of oxygen radicals at that site. ${ }^{43}$ The results presented here show that TQ is capable of binding to DNA as well as copper, and thus it would be reasonable to assume that a similar mechanism operates in the case of TQ-Cu(II)-mediated DNA cleavage. Thus, the mechanism proposed by us is an alternative, non-enzymatic and copper-dependent pathway for the cytotoxic action of certain anticancer agents that are capable of mobilizing and reducing endogenous copper. Such a common mechanism better explains the anticancer effects of antioxidants with diverse chemical structures as also the preferential cytotoxicity toward cancer cells.

\section{Materials and Methods}

Materials. TQ, DMSO, agarose (normal melting and low melting), phosphatebuffered saline $\mathrm{Ca}^{2+}$ and $\mathrm{Mg}^{2+}$ free, RPMl 1640 media, histopaque 1077, metal chelators (neocuproine, bathocuproine disulphonic acid, desferrioxamine mesylate and histidine), calf thymus DNA, cupric chloride were purchased from Sigma Chemical Co. (St. Louis, MO, USA). All other chemicals were commercial products of analytical grade.

Preparation of stock solutions of TQ. TQ was dissolved in DMSO just before use as stock of $3 \mathrm{mM}$. Upon addition to reaction mixtures, in the presence of buffers and at the concentrations used, the compounds remained in solution and did not lead to any appreciable change in $\mathrm{pH}$. To test any effect of solvent on the DNA breakage, DMSO solution was added to the cells at the final concentration of $2 \%(\mathrm{v} / \mathrm{v})$, which was the highest concentration of DMSO used in the test compound-treated reaction medium. No difference was observed with or without DMSO indicating that the DMSO at the tested concentrations did not influence the results.

Fluorescence studies. The fluorescence studies were performed on a Shimadzu spectrofluorometer RF-5310 PC (Kyoto, Japan). TQ was excited at $255 \mathrm{~nm}$ as denoted in legends to the figures and emission spectra were recorded in the range shown in figures.

Hydroxyl radical generation. Hydroxyl radical production by increasing concentrations of $\mathrm{TQ}$ in the presence of $50 \mu \mathrm{M} \mathrm{Cu}$ (II) was detected by the method of Quinlan and Gutteridge. ${ }^{24}$ Calf thymus DNA $(100 \mu \mathrm{g})$ was used as a substrate and the malondialdehyde generated from deoxyribose radicals was assayed by recording the absorbance at $532 \mathrm{~nm}$.

Isolation of lymphocytes. Fresh heparinized blood samples $(2.0 \mathrm{ml})$ from non-smoking healthy donors were obtained by venipuncture and diluted suitably in $\mathrm{Ca}^{++}$- and $\mathrm{Mg}^{++}$-free PBS for each experiment. Lymphocytes were isolated from blood using Histopaque 1077 (Sigma Diagnostics, St. Louis, MO, USA), and the cells were finally suspended in RPMI 1640.

Viability assessment of lymphocytes. The lymphocytes were checked for their viability before the start and after the end of the reaction using Trypan blue exclusion test. ${ }^{44}$ The viability of the cells was found to be greater than $93 \%$.

Alkaline single-cell gel electrophoresis (comet assay). Treatment of whole lymphocytes with TQ and the subsequent comet assay was performed essentially as described earlier. ${ }^{14,15}$ As the DNA breakage had to be compared with that in lymphocyte nuclei, the treatment of cells with $T Q$ was done on slides rather than in microcentrifuge tubes.

Cell lines and reagents. Prostate cancer cell lines PC3, LNCaP, DU145, C42B were obtained from ATCC (Manassas, VA, USA) and maintained in RPMI
1640 (Invitrogen, Carlsbad, CA, USA). The media were supplemented with $10 \%$ fetal bovine serum, $100 \mathrm{U} / \mathrm{ml}$ penicillin and $100 \mu \mathrm{g} / \mathrm{ml}$ streptomycin. All cells were cultured in a $5 \% \mathrm{CO}_{2}$-humidified atmosphere at $37^{\circ} \mathrm{C}$. Stock solution of $\mathrm{TQ}$ $(25 \mathrm{mM})$ was made by dissolving in DMSO and fresh stocks were made for every individual assay. The stock solutions of various chelators of metal ionsneocuproine/desferoxamine mesylate/histidine-were made in phosphate-buffered saline (PBS) at a final concentration of $50 \mathrm{mM}$ and were always made fresh just before experiments.

Cell growth inhibition studies by 3-(4,5-dimethylthiazol-2-yl)2,5-diphenyltetrazolium bromide (MTT) assay. Prostate cancer cells were seeded in 96-well microtiter culture plates. After overnight incubation, normal growth medium was removed and replaced with a fresh medium containing DMSO (vehicle control) or different concentrations of test compounds as indicated for individual experiments. Various chelators were added in individual assays as mentioned in respective experiments. After 3 days of incubation, $25 \mu \mathrm{l}$ of MTT solution $(5 \mathrm{mg} / \mathrm{ml}$ in PBS) was added to each well and incubated further for $2 \mathrm{~h}$ at $37^{\circ} \mathrm{C}$. Upon termination, the supernatant was aspirated and the MTT formazan, formed by metabolically viable cells, was dissolved in DMSO (100 $\mu$ l) by mixing for $30 \mathrm{~min}$ on a gyratory shaker. The absorbance was measured at $595 \mathrm{~nm}$ on Ultra Multifunctional Microplate Reader (TECAN, Durham, NC, USA). Each treatment had eight replicate wells and the amount of DMSO in reaction mixture never exceeded $0.1 \%$. Moreover, each experiment was repeated at least three times.

Histone/DNA ELISA for detection of apoptosis. The Cell Death Detection ELISA Kit (Roche, Palo Alto, CA, USA) was used to detect apoptosis in cancer cells treated with the test compounds, according to the manufacturer's protocol. Briefly, cells were treated with the compounds or DMSO control for $72 \mathrm{~h}$. After treatment, the cytoplasmic histone/DNA fragments from cells were extracted and incubated in the microtiter plate modules coated with anti-histone antibody. Subsequently, peroxidase-conjugated anti-DNA antibody was used for the detection of immobilized histone/DNA fragments followed by color development with ABTS substrate for peroxidase. The spectrophotometric absorbance of the samples was determined by using Ultra Multifunctional Microplate Reader (TECAN) at $405 \mathrm{~nm}$.

Statistical analysis. The statistical analysis was performed as described by Tice et al. ${ }^{45}$ and is expressed as \pm S.E.M. of three independent experiments. A Student's t-test was used to examine statistically significant differences. Analysis of variance was performed using ANOVA. $P$-values $<0.05$ were considered statistically significant.

\section{Conflict of Interest}

The authors declare no conflict of interest.

Acknowledgements. HZ, HYK and SA acknowledge CSIR, New Delhi, for awarding SRF to them. SMH acknowledges the UGC for awarding UGC-BFF to him.

1. Gali-Muhtasib HU, Abou Kheir WG, Kheir LA, Darwiche N, Crooks PA. Molecular pathway for thymoquinone induced cell-cycle arrest and apoptosis in neoplastic keratinocytes. Anticancer Drugs 2004; 15: 389-399.

2. Gali-Muhtasib H, Diab-Assaf M, Boltze C, Al-Hmaira J, Hartig R, Roessner A et al. Thymoquinone extracted from black seed triggers apoptotic cell death in human colorectal cancer cells via a p53-dependent mechanism. Int J Oncol 2004; 25: 857-866.

3. Shoieb AM, Elgayyar M, Dudrick PS, Bell JL, Tithof PK. In vitro inhibition of growth and induction of apoptosis in cancer cell lines by thymoquinone. Int J Oncol 2003; 22: 107-113.

4. Worthen DR, Ghosheh OA, Crooks PA. The in vitro anti-tumor activity of some crude and purified components of blackseed Nigella sativa L. Anticancer Res 1998; 18: 1527-1532.

5. Mansour MA, Nagi MN, El-Khatib AS, Al-Bekairi AM. Effects of thymoquinone on antioxidant enzyme activities, lipid peroxidation and DT-diaphorase in different tissues of mice: a possible mechanism of action. Cell Biochem Funct 2002; 20: 143-151.

6. Bolton JL, Trush MA, Penning TM, Dryhurst G, Monks TJ. Role of quinones in toxicology. Chem Res Toxicol 2000; 13: 135-160.

7. El-Mahdy MA, Zhu Q, Wang QE, Wani G, Wani AA. Thymoquinone induces apoptosis through activation of caspase-8 and mitochondrial events in p53-null myeloblastic leukemia HL-60 cells. Int J Cancer 2005; 117: 409-417.

8. Gali-Muhtasib H, Roessner A, Schneider-Stock R. Thymoquinone: a promising anti-cancer drug from natural sources. Int J Biochem Cell Biol 2006; 38: 1249-1253. 
9. Yi T, Cho SG, Yi Z, Pang X, Rodriguez M, Wang Y et al. Thymoquinone inhibits tumor angiogenesis and tumor growth through suppressing AKT and extracellular signalregulated kinase signaling pathways. Mol Cancer Ther 2008; 7: 1789-1796.

10. Adams JM, Cory S. The Bcl-2 apoptotic switch in cancer development and therapy. Oncogene 2007; 26: 1324-1337.

11. Koka PS, Mondal D, Schultz M, Abdel-Mageed AB, Agrawal KC. Studies on molecular mechanisms of growth inhibitory effects of thymoquinone against prostate cancer cells: role of reactive oxygen species. Exp Biol Med 2010; 235: 751-760.

12. El-Najjar N, Chatila M, Moukadem H, Vuorela H, Ocker M, Gandesiri M et al. Reactive oxygen species mediate thymoquinone-induced apoptosis and activate ERK and JNK signaling. Apoptosis 2010; 15: 183-195.

13. Gupte A, Mumper RJ. Elevated copper and oxidative stress in cancer cells as a target for cancer treatment. Cancer Treat Rev 2008; 35: 32-46.

14. Ullah MF, Shamim U, Hanif S, Azmi AS, Hadi SM. Cellular DNA breakage by soy isoflavone genistein and its methylated structural analogue biochanin A. Mol Nutr Food Res 2009; 53: 1376-1385.

15. Zubair H, Khan HY, Ullah MF, Ahmad A, Wu D, Hadi SM. Apogossypolone, derivative of gossypol, mobilizes endogenous copper in human peripheral lymphocytes leading to oxidative DNA breakage. Eur J Pharm Sci 2012; 47: 280-286.

16. Shamim U, Hanif S, Ullah MF, Azmi AS, Bhat SH, Hadi SM. Plant polyphenols mobilize nuclear copper in human peripheral lymphocytes leading to oxidatively generated DNA breakage: Implications for an anticancer mechanism. Free Radic Res 2008; 42: 764-772.

17. Khan HY, Zubair H, Ullah MF, Ahmad A, Hadi SM. Oral administration of copper to rats leads to increased lymphocyte cellular DNA degradation by dietary polyphenols: implications for a cancer preventive mechanism. Biometals 2011; 24: 1169-1178.

18. Ullah MF, Ahmad A, Khan HY, Zubair H, Sarkar FH, Hadi SM. The prooxidant action of dietary antioxidants leading to cellular DNA breakage and anticancer effects: implications for chemotherapeutic action against cancer. Cell Biochem Biophys 2011; doi:10.1007/ s12013-011-9303-4.

19. Hadi SM, Asad SF, Singh S, Ahmad A. A putative mechanism for anticancer and apoptosis inducing properties of plant-derived polyphenolic compounds. IUBMB Life 2000; 50: 1-5.

20. Hadi SM, Bhat SH, Azmi AS, Hanif S, Shamim U, Ullah MF. Oxidative breakage of cellular DNA by plant polyphenols: a putative mechanism for anticancer properties. Semin Cancer Biol 2007; 17: 370-376.

21. Nazeem S, Azmi AS, Hanif S, Ahmad A, Mohammad RM, Hadi SM et al. Plumbagin induces cell death through a copper-redox cycle mechanism in human cancer cells. Mutagenesis 2009; 24: 413-418.

22. Ahmad MS, Fazal S, Rahman A, Hadi SM, Parish JH. Activities of flavonoids for the cleavage of DNA in the presence of $\mathrm{Cu}(\mathrm{II})$ : correlation with the generation of active oxygen species. Carcinogenesis 1992; 13: 605-608.

23. Rahman A, Shahabuddin A, Hadi SM, Parish JH. Complexes involving quercetin, DNA and Cu(II). Carcinogenesis 1990; 11: 2001-2003.

24. Quinlan GJ, Gutteridge JMC. Oxygen radical damage to DNA by rifamycin SV and copper ions. Biochem Pharmacol 1987; 36: 36-39.

25. Bryan SE. Metal lons in Biological Systems. Marcel Dekker: New York, 1979.

26. Czene S, Tiback M, Harms-Ringdahl M. pH-dependent DNA cleavage in permeabilized human fibroblasts. Biochem J 1997; 323: 337-341.

27. Curtis C, Shah SP, Chin SF, Turashvili G, Rueda OM, Dunning MJ et al. The genomic and transcriptomic architecture of 2,000 breast tumours reveals novel subgroups. Nature 2012; 486: 346-352.

28. Gali HU, Perchellet EM, Klish DS, Johnson JM, Perchellet JP. Hydrolyzable tannins: potent inhibitors of hydroperoxide production and tumor promotion in mouse skin treated with 12-O-tetradecanoyl phorbol-13- acetate in vivo. Int J Cancer 1992; 51: 425-432.
29. Simpson JA, Narita S, Geiseg S, Gebicki S, Dean RT. Long-lived reactive species on freeradical-damaged proteins. Biochem J 1992; 282: 621-624.

30. Bhat SH, Azmi AS, Hadi SM. Prooxidant DNA breakage induced by caffeic acid in human peripheral lymphocytes: involvement of endogenous copper and a putative mechanism for anticancer properties. Tox App Pharm 2007; 3: 249-255.

31. Ahmed MS, Ramesh V, Nagaraja V, Parish JH, Hadi SM. Mode of binding of quercetin to DNA. Mutagenesis 1993; 9: 193-197.

32. Ahsan A, Hadi SM. Strand scission in DNA induced by curcumin in the presence of $\mathrm{Cu}(I I)$. Cancer Lett 1998; 124: 23-30.

33. Ahmad A, Asad SF, Singh S, Hadi SM. DNA breakage by resveratrol and $\mathrm{Cu}(\mathrm{II})$ : reaction mechanism and bacteriophage inactivation. Cancer Lett 2000; 154: 29-37.

34. Azam S, Malik A, Hadi SM. Prooxidant property of green tea polyphenols epicatechin and epicatechin-3-gallate: implications for anticancer properties. Toxicol In Vitro 2004; 18 : 555-561.

35. Lee BM, Park KK. Beneficial and adverse effects of chemopreventive agents. Mutat Res 2003; 523-524: 265-278.

36. Nagi MN, Mansour MA. Protective effect of thymoquinone against doxorubicin-induced cardiotoxicity in rats: a possible mechanism of protection. Pharmacol Res 2000; 41: 283-289.

37. Badary OA, Taha RA, Gamal el-Din AM, Abdel-Wahab MH. Thymoquinone is a potent superoxide anion scavenger. Drug Chem Toxicol 2003; 26: 87-98.

38. Simamura E, Hirai K, Shimada H, Koyama J, Niwa Y, Shimizu S. Furanonaphthoquinones cause apoptosis of cancer cells by inducing the production of reactive oxygen species by the mitochondrial voltage-dependent anion channel. Cancer Biol Ther 2006; 5: 1523-1529.

39. Kamal A, Ramu R, Tekumalla V, Khanna GB, Barkume MS, Juvekar AS et al. Synthesis, DNA binding, and cytotoxicity studies of pyrrolo[2,1-c][1,4]benzodiazepine-anthraquinone conjugates. Bioorg Med Chem 2007; 15: 6868-6875.

40. Bezerra DP, Alves AP, de Alencar NM, Mesquita Rde O, Lima MW, Pessoa C et al. Antitumor activity of two derivatives from 2-acylamine-1,4-naphthoquinone in mice bearing S180 tumor. J Exp Ther Oncol 2008; 7: 113-121.

41. Bhat R, Hadi SM. DNA breakage by tannic acid and $\mathrm{Cu}$ (II): sequence specificity of the reaction and involvement of active oxygen species. Mutat Res 1994; 313: 39-48.

42. Ullah MF, Khan HY, Zubair H, Shamim U, Hadi SM. The antioxidant ascorbic acid mobilizes nuclear copper leading to a prooxidant breakage of cellular DNA: implications for chemotherapeutic action against cancer. Cancer Chem Pharm 2011; 67: 103-110.

43. Pryor WA. Why is hydroxyl radical the only radical that commonly binds to DNA? Hypothesis: It has rare combination of high electrophilicity, thermochemical reactivity and a mode of production near DNA. Free Radic Biol Med 1988; 4: 219-233.

44. Pool-Zobel BL, Guigas C, Klein R, Neudecker C, Renner HW, Schmezer P. Assessment of genotoxic effects by lindane. Food Chem Toxicol 1993; 31: 271-283.

45. Tice RR, Agurell E, Anderson D, Burlinson B, Hartmann A, Kobayashi $\mathrm{H}$ et al. Single cell gel/Comet assay; guidelines for in vitro and in vivo genetic toxicology testing. Environ $\mathrm{Mol}$ Mutagen 2000; 35: 206-221.

(c) (5) Cell Death and Disease is an open-access journal (c) ${ }_{\text {BY }}$ SA licensed under a Creative Commons Attribution-NonCommercialShareAlike 3.0 Unported License. To view a copy of this license, visit http://creativecommons.org/licenses/by-nc-sa/3.0/ 